\title{
La administración del agua en el tránsito del Antiguo Régimen a la República. Aguascalientes, 1821-1835
}

Jesús Gómez Serrano*

UNIVERSIDAD AUTÓNOMA DE AGUASCALIENTES

Este artículo refiere las dificultades que hubo entre el cabildo de la villa de Aguascalientes y el latifundista más rico de la región por el control del agua para el abasto urbano y el riego de huertas en los años posteriores a la consumación de la independencia nacional. La creación de un nuevo marco jurídico, que incluía la Constitución federal de 1824 y la local del estado de Zacatecas, al que pertenecía el partido de Aguascalientes, alteró por completo las reglas del juego, lo que propició que los actores se movieran con torpeza en la nueva arena. El antiguo marco jurídico no desapareció de la noche a la mañana y el nuevo tardó decenios en incorporarse a la práctica cotidiana. Con el ánimo de colocar el tema en su adecuada perspectiva, se propone en los primeros apartados una reseña de la forma en que se administró el agua en la época virreinal.

(Agua, usos, Cabildo, negociaciones, conflicto)

1 propósito de este trabajo es ilustrar las dificultades que hubo en la villa de Aguascalientes entre el cabildo y un poderoso particular por el control del agua en los ańos inmediatamente posteriores a la consumación de la independencia nacional. Con el ánimo de colocar el tema en su adecuada perspectiva y entender mejor los cambios que se dieron después de 1821, propongo en los primeros apartados una reseña de la forma en que se administró el agua en la época virreinal. La creación de un nuevo marco jurídico (Constitución Federal de 1824, constituciones locales y leyes secundarias) comenzó a alterar las reglas del juego, lo que propició que los

*jgomez@correo.uaa.mx 
actores se movieran con cierta torpeza en la nueva arena. El antiguo marco jurídico, que en el campo de los derechos sobre agua consistía en un "conjunto flexible, realista y polifacético, además de principios dogmáticos y usos administrativos”, no desapareció de la noche a la mañana, ni podía entrar en desuso por un acto de autoridad (Margadant 1989, 145). Además, hay que tener en cuenta que el nuevo orden jurídico no tardó años, sino decenios en perfeccionarse e incorporarse a la práctica cotidiana. Lo que tuvimos durante todo el siglo XIx fue una mixtura. En lo tocante al agua, sólo la Ley General de Vías de Comunicación de 1888 inició un proceso de centralización y control del recurso a favor del gobierno federal (Aboites 1998, 25; Sánchez 2005, 12, 142-144).

Los resultados de este pasaje fueron muchas veces paradójicos, pues los nuevos cabildos constitucionales, que orgullosamente se sentían parte orgánica de lo que un regidor llamó "nuestro feliz sistema republicano federal", seguían invocando los privilegios amparados por el antiguo régimen y su legislación para imponer sus derechos a los particulares. Estos, por su parte, aunque no podían invocar en su auxilio privilegios estamentales o títulos de nobleza (ya abolidos), se valían de su dinero, la destreza de sus abogados, los vacíos y ambigüedades de la ley, las pugnas entre autoridades municipales y estatales y los privilegios con que contaban las clases en ascenso, particularmente los militares. El fuero militar podía ser utilizado por un miembro de la defenestrada nobleza para impedir que el cabildo procediera en su contra o, por lo menos, para retrasar la aplicación de medidas o entorpecer su proceder. Se anunciaba en estos pleitos uno de los problemas hasta la fecha no resueltos por el Estado liberal; la dificultad de arbitrar justicia entre desiguales; la incapacidad de las instituciones ante el poder de algunos particulares; y la capacidad de éstos para retorcer la ley en provecho de sus intereses.

\section{Nombre Y RAZÓN DE SER DEL LUGAR}

Una primera prueba del papel central que ha tenido el agua en la historia de la ciudad de Aguascalientes la encontramos en su nombre mismo. Se trata de una prueba simbólica, si se quiere, pero ilus- 
trativa de la importancia crucial que se le concedió desde un principio a este recurso. El lugar se fundó como villa en 1575, en el contexto de la guerra chichimeca, con el propósito de contribuir a la pacificación del Norte y asegurar los caminos que iban a las minas de Zacatecas. En rigor, fue una promoción hecha por particulares, refrendada por el presidente de la Audiencia de Guadalajara (Gómez 2001, 46-63). Su nombre original fue villa de la Ascensión, que después cambió a favor de villa de la Asunción (Gutiérrez 1998, 202-207).

Casi al mismo tiempo empezó a usarse la denominación más concisa y descriptiva de villa de las Aguas Calientes. El cambio nunca fue oficial, pero en los primeros ańos del siglo XVII, cuando se erigieron la parroquia y la alcaldía mayor, el nuevo nombre había recibido ya una especie de sanción por su creciente uso. Debe decirse que esta denominación es anterior a la fundación de la villa, pues en las primeras mercedes de tierra que se concedieron en la zona (1565-1566) se alude al "sitio de aguas calientes", o a las tierras de los chichimecas, "donde dicen Aguascalientes" (Topete 1980, 1820). Esta denominación era medianamente popular en la época de la fundación de la villa, como lo prueba la alusión que hay en la cédula de fundación a las casas que había construido Alonso Ávalos de Saavedra "en el sitio y paso que dicen de Aguas Calientes" (Gómez 2001, 43). Las autoridades de la villa tendrían muchas oportunidades de mostrar la importancia del nombre durante la época colonial. En sentido estricto, Aguascalientes no era sólo un nombre, sino la razón de ser del poblado. A mediados del siglo xvinI, el historiador Matías de la Mota $(1973,54)$ recordaba que el lugar le debía su nombre a "unos baños de aguas calientes muy saludables, que están a distancia de media legua de la dicha villa".

\section{LA COMPOSICIÓN DE I644}

En octubre de 1643, el visitador Cristóbal de Torres estuvo en la villa, facultado para mercedar tierras, regularizar demasías, entrar en composiciones con los particulares, proteger a los naturales, promulgar ordenanzas y tomar medidas conducentes al mantenimiento de los privilegios del lugar (Calvo 1991, 7). En lo tocante al agua, 
encontró que reinaba la más completa anarquía, lo que propiciaba acaparamientos, rińas entre los vecinos y hasta "ofensas a Dios". Basado en "informes ciertos" afirmó que

la causa principal de haberse fundado dicha villa fue el ojo de agua caliente que a ella venía, y que estando en costumbre gozaren todos los vecinos de ella, no lo hacían porque los poderosos y otros que a título de decir tenían siembras de trigo y otras semillas, sacaran y quitaran la dicha agua de la acequia principal, sangrándola por diferentes partes, con que los pobres perecían y no iba en aumento la dicha fundación, todas causas en gran daño y deservicio de ambas majestades.

El problema era grave y exigía un "breve remedio". Investido como estaba de facultades omnímodas, decidió revocar "todas y cualquier mercedes o derechos que poseían [los vecinos] a dicha agua y se aprovechaban de ella para su riego". Además, dispuso que "ninguna persona de cualquier estado o calidad y dignidad que fuese no impidiese a que la dicha agua viniese a esta dicha villa por la acequia principal de ella, venero y natural curso, sin sangrarla ni abrir otra ninguna acequia, mayor ni menor, fuera ni dentro de la villa”, amenazando a los infractores con severas penas. ${ }^{1}$

El bachiller Alonso Muñoz de Huerta, uno de los "poderosos" aludidos, le pidió al visitador permiso para usar "los remanentes" del agua, lo que fue objetado por una junta de vecinos, que ofreció "servir a Su Majestad" con una composición de doscientos pesos, a cambio de la cual la villa recibiera en toda forma una merced que asegurara la propiedad corporativa del recurso y le permitiera al cabildo reglamentar su uso y distribución. Los demandantes alegaban

${ }^{1}$ Auto levantado el 3 de octubre de 1644, entre las fojas 15-17 de un legajo proveniente de los archivos de Zacatecas al que en lo sucesivo llamo Documento Paullada. Se trata de diversos testimonios relacionados con los derechos que tenía la villa a las aguas de los manantiales del Ojocaliente reunidos en 1831 por el gobierno del estado de Zacatecas a solicitud del ayuntamiento de Aguascalientes. Hacia 1950, cuando Chevalier escribía su estudio sobre el latifundismo mexicano había varias copias de este expediente en el Archivo Municipal de Zacatecas, que desgraciadamente no se sabe a dónde fueron a parar (Chevalier 1976, notas 92, 101 y 103 al capítulo vi, 460-461). El Lic. Fernando Paullada me obsequió una copia fotostática de dicho documento, autentificada por notario. 
que la villa se había fundado "a título" del agua del manantial y que a principios del siglo XVII, cuando el recurso había sido repartido por el presidente de la audiencia de Guadalajara no se habían hecho mercedes "para caballerías de tierra, sino para suertes de huerta". De esta manera, las "labores de riego" que mantenían los ricos iban "en gran dańo de la república y vecinos de ella”. Amparados por este argumento, los vecinos pidieron que "les admitiese en forma de villa a composición en dicha agua [...] y que siendo suya, se fundarían y agregarían más vecinos". Además, exigieron la destrucción de "las labores de trigo que se sembraban a título del dicho ojo de agua" y pidieron que los remanentes, "después de los riegos de las huertas y servicio de sus casas" [de los vecinos], pudieran ser vendidos y repartidos, aplicándose el dinero así obtenido "para propios y gastos de su república y festividades". ${ }^{2}$

El visitador estuvo de acuerdo y fijó el precio de la composición en mil pesos, destinados a la Armada de Barlovento, como era costumbre en la época. El 30 de septiembre de 1644, de regreso en Aguascalientes, Torres aceptó formalmente la composición ofrecida por los vecinos de la villa y fijó los plazos para el pago. Los mil pesos debían prorratearse entre los vecinos, "conforme cada uno tuviere las tierras, huertas, vińas y chilares”. El visitador dictó además algunas normas generales relacionadas con el uso del agua, amenazando a los infractores con penas muy severas, que incluían multas en efectivo y la pérdida de las suertes de huerta y las mercedes de agua. ${ }^{3}$ De esta manera, la Corona, que era propietaria originaria del recurso (Margadant 1989, 114), lo mercedó onerosamente a la corporación municipal y le otorgó un título que ampararía sus derechos durante los siguientes tres siglos, convirtiéndola en "la figura clave en el manejo

${ }^{2}$ Documento Paullada, fojas 17-26. El énfasis es nuestro.

${ }^{3}$ Documento Paullada, fojas 26-36. Calvo $(1991,7)$ dice que en manos de funcionarios corruptos la visita podía ser un instrumento de extorsión para los vecinos de los lugares visitados y de rápido enriquecimiento para los visitadores, y agrega que la que practicó Cristóbal de Torres en 1643-1644 "acarreó tantos excesos que el rey tuvo que intervenir prohibiendo este procedimiento administrativo", por lo que "durante más de cuarenta ańos no se realizó ya ninguna visita". No deja de sorprender lo que se dice de esta visita, porque las medidas que adoptó en la alcaldía mayor de Aguascalientes fueron extremadamente benéficas y trascendentes. 
del agua" (Aboites 1998, 31). En términos muy típicos de la época, este título de composición implicó la regularización de una situación anómala (Chevalier 1976, 326-338; Margadant 1996, 284).

Debe añadirse que el rol protagónico que el título de composición atribuyó al cabildo no excluyó intervenciones de terceros, en concreto del alcalde mayor y sobre todo de la Audiencia de Guadalajara, la cual, a lo largo de toda la época virreinal, siguió mercedando tierras y aguas a los particulares que lo solicitaban, sin tomar el parecer de la corporación. Con mucha frecuencia veremos a los regidores ejecutando los mandatos de la Audiencia y dando posesión a los vecinos de las mercedes despachadas en Guadalajara. En este sentido habría que matizar la afirmación de Aboites de que el cabildo era "la figura clave", pues su competencia en temas de agua no era exclusiva.

Aparentemente, las medidas dictadas por el visitador Torres atacaban en su raíz los problemas derivados del uso y distribución de aguas. En forma clara constituyen un reflejo en el nivel local de la forma gradual en que en la Nueva Espańa, particularmente en las resecas provincias de tierra adentro, se fue tomando conciencia de la necesidad de reglamentar el uso del agua. En 1654, un oidor repartió las aguas del río Querétaro entre el cabildo, la "república de espańoles", los conventos de religiosos y los indios que en gran número poblaban el lugar; los términos del reparto fueron formalmente pregonados, pese a lo cual no lograron erradicarse fraudes y abusos (Suárez 1998, 41-47; Margadant 1996, 285-288).

Estas medidas le dan la razón a Tortolero (2000, 41-42), quien sostiene que sólo a mediados del siglo XviI se abandonó la idea de que las aguas eran un recurso de dominio público, "de la misma forma que los pastos y los bosques"; el crecimiento de la demanda obligó a las autoridades a reglamentar el acceso al agua, fueron las mercedes y composiciones los medios de los que más frecuentemente se echó mano. El autor agrega que de esta manera se introdujo un criterio según el cual el agua se repartía en proporción al poder de los solicitantes, lo que explica la forma en que conventos, establecimientos industriales, funcionarios y vecinos influyentes la acapararon. Aunque, siguiendo a Sánchez $(2005,66)$, habría que añadir que el control que ejercían "las grandes y medianas unidades productivas" 
sobre la tierra y el agua no impidieron la supervivencia ni la formación de nuevas comunidades indígenas y pequeñas propiedades.

\section{LOS CHILARES DE LOS POBRES Y LOS TRIGALES DE LOS RICOS}

La composición de 1644 fue un intento de resolver el problema del agua en la villa de Aguascalientes, pero su eficacia fue sólo provisional, pues la villa siguió creciendo, se formaron nuevos barrios, el número de huertas se multiplicó y nunca se abandonó el sistema de distribución de agua a base de acequias al aire libre ni el método de riego mediante la inundación de los terrenos. A largo plazo, lo que la composición perfiló fue un conflicto entre los vecinos viejos de la villa y sus descendientes, protegidos por la medida, y los vecinos de los nuevos barrios, que no tenían mercedes pero necesitaban agua para regar sus sementeras.

El principal actor de las dificultades que se dieron durante la segunda mitad del siglo Xvir fue el barrio de Triana, que apenas y se menciona en el título composición. Este barrio se formó del otro lado del pequeño río que por el sur formaba el límite natural de la villa, un escurrimiento que sólo llevaba agua en época de lluvias y que después se conoció como arroyo de Los Adoberos, aunque en la época virreinal era habitualmente referido como "arroyo de la villa", la frontera física entre ésta y el nuevo barrio de Triana. En 1674, los cultivos estaban muy extendidos en Triana, lo que en principio no molestaba a nadie, pero el alcalde mayor Nicolás de Zaldívar observó que la villa carecía de propios y que cuando se necesitaba dinero había que "molestar" a los vecinos "echándoles repartimientos". Valiéndose de su autoridad obligó a "todos los vecinos del barrio de Triana" a pagar "en cada un año cincuenta pesos para dichos propios", a cambio de lo cual podrían acceder legalmente al agua del manantial del Ojocaliente. ${ }^{4}$ En apariencia el alcalde resolvió el problema de la falta de propios, pero sin advertirlo incubó otro, acaso mayor: la disputa entre la villa y el barrio de Triana por el control del agua. En lo sucesivo, usando como argumento el hecho de que pa-

${ }^{4}$ AHEA, Fondos Especiales (FE), 2, 2. 
gaban propios, los de Triana alegarían que tenían el mismo derecho al líquido que los "vecinos viejos" de la villa, favorecidos por la composición de 1644. La documentación nos permite adivinar que hubo tensiones y enfrentamientos, hasta que en mayo de 1683 se llegó a un nuevo acuerdo, fijándose en cien pesos la aportación anual al ramo de propios y, cosa muy importante, regulándose la cantidad que correspondía a Triana: "la tercia parte del agua [...] la cual han de llevar desde la presa por la acequia, dejando aparte las otras dos para esta dicha villa". ${ }^{5}$

Pero ello tampoco resolvió el problema. En 1701 estalló una nueva crisis, con la novedad de que la lista de acaparadores estaba encabezada por los más importantes funcionarios del cabildo, personajes "que por los cargos que obtienen se deja entender habían de aprovecharse del agua antes que los pobres", según se llegó a decir. El agua escaseaba en las huertas y cocinas de la villa, y hasta en las pilas de agua bendita de las iglesias, mientras que estos personajes la "divertían" regando sus plantíos de trigo. El procurador de la villa abrazó con pasión el partido de los quejosos y le pidió al alcalde mayor Diego de Parga y Gayoso, que prohibiera sembrar trigo, "pues de sembrarse es de mucho perjuicio a esta villa y a sus vecinos, los que tienen huertas, y los que no, la falta de agua en lo común, pues todos se quejan no tienen ni aún que beber, porque muchos pobres no tienen quien se las acarree, y los demás sus huertas se secan por falta de agua". ${ }^{6}$ Curiosamente no se hizo ninguna alusión a los trigales que había en el barrio de Triana, donde el alcalde mayor tenía su huerta, por lo que se supo, una de las mejor regadas.

Parga y Gayoso, que como abogado de la real audiencia era diestro en el manejo equívoco de los formalismos legales, dijo recibir de buen grado la solicitud, e incluso añadió que los vecinos del barrio de La Merced y los religiosos del convento de San Diego se habían quejado por la falta de agua, habiendo "muchos pleitos y debates [...] sobre querer llevar cada uno el agua y ser de las primeras personas del lugar quienes lo impedian”. ¿ No era el propio alcalde mayor una

${ }^{5}$ AHEA, FPN, caja 2, exp. 7, núm. 19, fojas 33f-34f.

${ }^{6}$ Documento Paullada, fojas 95-96. 
de esas "primeras personas"? No lo aclaró, pero mandó que el martes primero de noviembre de 1701 se pregonara "[que] ninguna persona de cualquier calidad o condición que sea, alcalde ordinario o capitular, siembre trigo en poca ni mucha cantidad, en la parte que dicho procurador refiere". Ańadía que el trigo "sólo se pueda sembrar en el Barrio de Triana”, que era precisamente donde él tenía su huerta. ${ }^{7}$

Las cosas dieron un giro imprevisto en 1702, cuando el capitán Fernando Delgado y Ocampo asumió el cargo de alcalde mayor. Originario del puerto andaluz de Sanlúcar de Barrameda, ${ }^{8}$ Delgado era el prototipo del funcionario de provincia que no estaba personalmente implicado en los negocios de la región a su cargo. En teoría y por razones obvias, los alcaldes mayores debían ser ajenos a las regiones que gobernaban (Rojas 1998, 193), pero muchas veces esto no se respetaba, como lo demuestra el caso de Parga y Gayoso, cuyo padre había sido alcalde de la misma jurisdicción apenas veinte años atrás y conservaba ahí sus negocios. ${ }^{9}$ En agosto de 1702 un grupo de diez modestos chileros del barrio de Triana denunció ante Delgado "los muchos y graves daños que tenemos con pérdida de nuestro corto caudal en los años antecedentes en las cosechas de nuestros chilares por causa de los trigos que se siembran, así en este barrio como en los alrededores de esta villa". Esas siembras eran propiedad de "los ricos" y de "los señores capitulares, por cuyo respeto se nos siguen las pérdidas dichas". Los quejosos recordaban la prohibición de sembrar trigo dictada el año anterior por el alcalde Parga y Gayoso, pese a la cual "vimos que se sembraba con más abundancia”. Los chileros pedían que volviera a publicarse la composición ajustada con el oidor Torres y que se hiciera efectiva la prohibición de sembrar trigo y regarlo con agua del Ojocaliente. ${ }^{10}$

Hasta ahí las cosas parecían ajustarse al guión conocido. Nadie se sorprendió tampoco cuando el alcalde mayor pidió un traslado de

${ }^{7}$ Documento Paullada, fojas 96-98. El énfasis es nuestro.

${ }^{8}$ Su testamento en AHEA-FPN, caja 83, exp. 2, 77f-80f.

${ }^{9}$ En su testamento, otorgado el primero de febrero de 1697, Joseph de Parga y Gayoso se decía "vecino y labrador en esta villa de Aguascalientes y regidor decano en el cabildo de la ciudad de Zacatecas". AHEA, FPN, caja 3, exp. 4, 25, 35f-36v.

${ }^{10}$ Documento Paullada, fojas 102-105. 
"los autos y asiento de la villa", sobre todo de la muy invocada composición de 1644. El 10 de agosto de 1702, sin embargo, Delgado y Ocampo ordenó que se pregonara un auto en el que lisa y llanamente declaraba que "con la siembra de los trigos que se hace en esta villa se sigue notable perjuicio generalmente a todos los vecinos de ella, pues además de perderse las huertas en que están fundadas y vinculadas capellanías, pierden los pobres sus chilares por falta de riego, y gastarse toda el agua en los trigos que los poderosos siembran". Esas anomalías daban origen a "muchos disgustos y ruinas, sobre que siempre hay heridas y descalabradas". Por esas razones ordenaba que "ninguna persona de cualquier estado o condición que sea se adelantase ni sea osado a sembrar trigo" y amenazaba a los infractores con una multa de cincuenta pesos. ${ }^{11}$

$\mathrm{Al}$ mismo tiempo, Delgado se dio a la tarea de reunir diversos testimonios relacionados con el uso de aguas públicas en los campos de trigo. El procurador general testimonió que la prohibición de sembrar trigos promulgada el año anterior había sido burlada por el propio alcalde mayor Parga y Gayoso, el depositario de la villa, el provincial de la Hermandad y varios alcaldes ordinarios, "personas que por los cargos que obtienen se deja entender habían de aprovecharse del agua antes que los pobres, por ser justicias y regidores", a pesar de que "dichos caballeros" no pagaban propios y los pobres sí. ${ }^{12}$ A este testimonio se añadieron otros, en conjunto un grueso legajo que constituye una radiografía muy precisa del problema, salpimentada con "esos picantes detalles" que anticipan la novela costumbrista del siglo xx (Chevalier 1976, 276-277).

$\mathrm{El}$ alegato era contundente y exhibía los graves inconvenientes que se derivaban de la siembra de trigos en la villa y desnudaba las maniobras de los cultivadores, la intervención interesada de diversos alcaldes mayores y los abusos de los regidores que no pagaban propios, pero ocupaban el agua del común regando sus propias huertas. Satisfecho tal vez por haber culminado una tarea que se antojaba imposible y que ciertamente ninguno de sus antecesores se había

${ }^{11}$ Documento Paullada, fojas 106-108.

${ }^{12}$ Documento Paullada, fojas 109-114. 
atrevido a emprender, el alcalde mayor Delgado y Ocampo certificó los autos y los remitió a la audiencia de Guadalajara "para la determinación de todo”. Además, hizo pregonar un auto que decía que mientras llegaba la sentencia deberían suspenderse todas las siembras de trigo, bajo pena de que el que lo contraviniere diera "por perdidos los bueyes, rejas y demás instrumentos de arar que se aprehendieren". ${ }^{13}$

Todo ello implicaba un desafío abierto a los funcionarios del cabildo que cultivaban trigo y no pagaban propios, los cuales le reclamaron airadamente al alcalde mayor que su auto se hubiera hecho "sin consulta de los capitulares". ${ }^{14}$ El conflicto escaló un peldaño más cuando el escribano les notificó la prohibición a los interesados, pues eran personajes ricos e influyentes, acostumbrados a actuar según su capricho y a torcer, cuando era necesario, el sentido de las medidas oficiales. La reacción del alcalde ordinario Manuel de la Cueva es bastante ilustrativa del enojo que había entre los poderosos y antes intocables cultivadores de trigo. De la Cueva le arrebató al escribano los papeles, diciéndole que él los leería, pero fue apremiado para que leyera en voz alta, cosa que hizo de mala gana. Con altanería le ordenó al escribano: "diga usted al alcalde mayor que ya me dio los autos, que yo responderé", e hizo el intento de guardar los documentos en alguna alacena de su tienda, lo que provocó cierto forcejeo. Fuera de sí, de la Cueva dijo "muchas palabras injuriosas", entre otras que debería dar "de palos a quien viniera a notificarle [autos]", pues "a los señores alcaldes ordinarios no se notifican autos, que si su merced proveía alguno contra el alcalde mayor, que si iría a notificarlo yo [el escribano], a que dije que si era en virtud de autos y con los fundamentos de aquel y con parecer de asesor, que sí iría, a que dijo que era yo un bruto". ${ }^{15}$

El alcalde mayor no se arredró ante las presiones ni se dejó chantajear por los poderosos, pero tampoco tenemos evidencias de que haya logrado erradicar la siembra de trigos o impedido que los ricos de la villa, con el exalcalde Parga y Gayoso a la cabeza, regaran sus trigales. El año de 1703, segundo y último de su gestión, transcurrió

${ }^{13}$ Documento Paullada, foja 133.

${ }^{14}$ Documento Paullada, fojas 153-155.

${ }^{15}$ Documento Paullada, fojas, 129-144. 
en medio de una tensa calma, a la espera de la resolución que pudiera dictar la audiencia. El encono era grande y por momentos los "disturbios" parecían inminentes, pero de alguna manera se evitó que la sangre llegara al río.

\section{¿UN PROBLEMA RESUELTO?}

Finalmente, el 26 de enero de 1704, cuando Delgado y Ocampo había dejado el cargo de alcalde mayor, llegó la respuesta de Guadalajara. Una respuesta contundente, en el sentido de que debía respetarse en todos sus términos la composición de aguas hecha con el visitador Torres en 1644, lo que implicaba la vigencia de la prohibición de sembrar trigo en las huertas de la villa, pero también tardía, pues el principal promotor del asunto había dejado su cargo, mientras que los "hombres ricos y poderosos" que lo habían desafiado, tal vez esperando simplemente que pasara el tiempo y las aguas recobraran en forma natural su nivel, seguían en la villa, obviamente defendiendo sus intereses de siempre. Lo que sucedió parece una ilustración perfecta del "acátese pero no se cumpla", herencia del derecho castellano medieval que permeaba toda la vida de la Nueva España, ese dualismo que implicaba que los tribunales cumplían su papel de garantes de la ley y al mismo tiempo abrían rendijas por las que se colaban muchas prácticas dudosas (González Alonso 1980). A veces todo el arte consistía en dejar pasar un poco de tiempo, el necesario para que la autoridad que con tanta energía había denunciado los abusos terminara su gestión y diera el paso a otra, que se coludiera con los poderosos lugareńos de la manera acostumbrada. Se respetaban rigurosamente las formas y los tribunales cumplían con su deber, pero los abusos no se extirpaban de raíz, por la sencilla razón de que había muchos intereses en juego. Lockhart (1982, 90) alude al "desmedido respeto de los españoles por la palabra escrita", lo que vale en particular para los formalismos legales, pero advierte que ello no implicaba su observancia práctica; en otras palabras, "obedézcase pero no se cumpla".

La sentencia, que fue dictada poco más de un año después de que el expediente fuera remitido a Guadalajara por el alcalde Delga- 
do, glosaba puntillosamente los recursos interpuestos por las partes y concluía con un mandato de enérgica apariencia:

que ninguna persona de cualquier estado y calidad que sean en dicha villa, ni en sus contornos, siembre trigo, cebada ni maíz que haya de regar con el agua de dicho ojo caliente, ni la divierta en otros efectos que los de regar sus huertas, vińas y chilares, y en los usos de las casas de vecindad, las de sus comunidades y fábricas, lo cual cumplan, pena de cien pesos cada uno.

Los campos que estuvieran sembrados con trigo o cebada serían destruidos. Al alcalde Manuel de la Cueva, el depositario y a otras autoridades locales se les haría saber "que las notificaciones que de autos de su alcalde mayor se les hicieren las oigan con toda obediencia y respondan con la modestia que están obligados, pena que se procederá contra ellos con todo rigor". ${ }^{16}$

El alcalde mayor Francisco del Árbol y Bonilla recibió el mandato de la audiencia el 14 de marzo de 1704 y se declaró "presto a la ejecución y cumplimiento". Sin embargo, en forma que puede parecer circunstancial, pero que conociendo la expectación que había en la villa resulta claramente sospechosa, pues daba a los cultivadores de trigo el tiempo que necesitaban para levantar su cosecha o destruir por sí mismos sus plantíos, evitándose la humillación pública a que habían sido sentenciados, dejó correr dos semanas de marzo y todo el mes de abril, pues según explicó estaba concluyendo "diferentes negocios de la Real Audiencia de este reino" en la provincia de Juchipila, que en ese tiempo estaba agregada a la alcaldía mayor de Aguascalientes. ${ }^{17}$ Por fin, publicó la sentencia el domingo 1 de mayo de 1704, "después de misa mayor, en concurso de mucha gente". Enseguida, como presumía que en la villa y sus contornos había "algunas sementeras de trigo", le pidió al alcalde del pueblo de indios de San Marcos que reuniese a su gente y valiéndose de las bestias destruyera esos plantíos. Como era de esperarse, el repartidor de las aguas sólo pudo señalar la existencia de dos plantíos, uno que

${ }^{16}$ Documento Paullada, fojas 58-69.

${ }^{17}$ En Aguascalientes el trigo era un cultivo de invierno: se sembraba en noviembre y se cosechaba precisamente a fines de abril. 
pertenecía al provincial de la Hermandad Nicolás de Esparza y otro "muy pequeño" en casa de Nicolás Valerio. Ambos fueron talados por las bestias, lo que constituyó una forma muy vistosa y casi teatral de cumplir el mandato de la audiencia e impartir justicia. ${ }^{18}$

Todo parece indicar que la ejecución de la sentencia satisfizo la recurrente exigencia de justicia de los pequeńos cosecheros, disipó las dudas relacionadas con la prohibición de sembrar trigos, resolvió en su raíz el grave problema de abasto de agua que aquejaba a la villa e incluso implicó la pública humillación de esas "primeras personas" que validas de sus cargos se aprovechaban del recurso "antes que los pobres". Sí, de acuerdo, pero hasta cierto punto se trataba de un juego de apariencias, como si fuera una representación teatral, según acabamos de sugerir. Hay que tener cuidado de no caer en la trampa que parece tendida a propósito por un expediente judicial tan voluminoso, una sentencia de apariencia tan contundente y un alcalde tan ladino, afirmando como Chevalier $(1976,276)$ que "así concluía una larga disputa”. En realidad no concluyó nada: sólo se le echó un poco de tierra al problema y en forma un tanto barroca se reconoció que era imposible zanjar la controversia en términos satisfactorios para todas las partes interesadas. Como dijo el apoderado de los padres del convento de La Merced un poco más adelante y en otro contexto, las quejas presentadas ante los tribunales eran objeto de "maliciosos traslados y dilaciones reprobadas por derecho". ${ }^{19}$ Como tantas otras veces, el juego de las demandas, las sentencias y las apelaciones cubría en forma impecable el lado jurídico-formal de la cuestión y las instituciones encargadas de administrar justicia hacían su trabajo, pero sin entrar al fondo de la cuestión, y no por negligencia o porque los poderosos de las villas españolas fueran siempre capaces de torcer a su favor el curso de la justicia. ${ }^{20}$ La razón de fondo era otra y, en cierta forma, escapaba a la capacidad de comprensión

${ }^{18}$ Documento Paullada, fojas 69-72.

${ }^{19}$ Documento Paullada, foja 76.

${ }^{20}$ Viene a cuento la observación de Margadant (1996, 304): "Algo de pasión a favor de los marginados siempre conviene al historiador, pero no debemos caer a priori en el extremo de considerar que todas las personae miserabiles hayan sido huérfanos y viudas maltratados por Shilocks". 
de los protagonistas de estas historias. Tenía que ver con la forma inextricable en que los intereses de los barrios, los propietarios de las huertas y las corporaciones (el cabildo de la villa española, los chileros de Triana, el pueblo de indios de San Marcos) se habían ido anudando, hasta el punto en que era prácticamente imposible determinar cuáles intereses eran legítimos y cuáles no. También tenía que ver, y mucho, con el carácter estacional de la demanda de agua, que disminuía al mínimo durante la época de lluvias (junio-septiembre) y crecía hasta el máximo, adquiriendo un carácter explosivo, durante las últimas semanas del estiaje (mediados de abril a fines de mayo), cuando todos los cultivadores veían con gran preocupación que sus huertos y sembradíos se secaban.

En realidad, con sólo transcurrir el tiempo había hecho la mayor parte del trabajo. El tiempo, o para mejor decir, los tiempos de la justicia, de suyo largos, pero más en un país tan dilatado como la Nueva Galicia (Calvo 1991, 33-35). Más de un año transcurrió entre el momento en que la investigación fue remitida a Guadalajara y la fecha en que la Audiencia dictó sentencia. Otros tres meses cruciales pasaron para que el alcalde mayor publicara la sentencia y castigara a los transgresores. La sentencia estaba a tono con lo que el exalcalde mayor Delgado y sus defendidos proponían, pero irónicamente, como si se tratara de un principio de compensación, el tiempo había transcurrido a favor de los ofensores y en cierta forma había vuelto nugatorio el mandato de la Audiencia, le había quitado su filo y contundencia a la sentencia. La justicia había triunfado, pero Parga y Gayoso y los demás "poderosos” sabían que las cosas no eran lo que parecían y que esa victoria tenía un carácter pasajero, apenas simbólico. Eran apenas dos "pedacillos" de trigo los que se habían destruido, pero lo más importante era que las antiguas prácticas retońarían y el agua volvería a sus trigales, hasta que de nueva cuenta apareciera un alcalde tan obstinado como Delgado, alguien que en lugar de coludirse ventajosamente con "los poderosos", abrazara en forma quijotesca la causa de los "pobres chileros" y se empeñara en que la justicia brillara para ellos.

No podemos, en el marco de este artículo, hacer una crónica detallada de los problemas que a lo largo del siglo XviII se suscitaron 
a causa del agua. Abreviemos diciendo que la documentación disponible sugiere que esos problemas se contaban entre los más importantes que tenían que enfrentar los alcaldes mayores cuando llegaban a la jurisdicción. Todos se informaban, estudiaban con atención las antiguas composiciones, escuchaban a los quejosos, prestaban oídos a los indios de San Marcos y a los chileros del barrio de Triana, visitaban el manantial, constataban el mal estado de las acequias, lamentaban la forma en que se desperdiciaba el agua y practicaban diversas diligencias, pero evidentemente eran incapaces de remediar el problema. Sin excepción, los alcaldes terminaban más o menos aturdidos, sin saber qué hacer, tal vez convencidos de que el problema no tenía solución. Los menos dados a las componendas, como Delgado y Ocampo en 1702, se aferraban a la composición ajustada con el visitador Torres en 1644 y a la prohibición de sembrar trigos promulgada por la Audiencia de Guadalajara en 1704. Ratificaban las prohibiciones, amenazaban a los infractores y ordenaban la destrucción de algunas sementeras, con lo que, de paso, tal vez vengaban algún agravio personal.

Podían pasar años durante los que la abundancia de lluvias y otras circunstancias se confabulaban a favor de los cultivadores de trigo, a quienes nadie molestaba con inoportunos recordatorios, pero cuando la rueda de la historia completaba su giro y se presentaba de nuevo un ciclo de escasez se recordaba que había en los archivos previsiones muy dignas de tomarse en cuenta, como si fuera posible exorcizar a base de pregones el fantasma de la falta de agua. Los grandes episodios de crisis normalmente se presentaban en la fase más recia del estiaje, a fines de abril o principios de mayo, y entonces se veía de nuevo el lastimoso espectáculo de los vecinos agraviándose entre sí, las “ofensas a Dios”, las quejas de los graves ministros del culto que carecían de agua en las pilas de sus iglesias, las doncellas bajando al río para echar viajes de agua, los lamentos de los chileros del barrio de Triana y las denuncias de los indios de San Marcos. La representación no era nueva, pero todos se entregaban a ella con la vehemencia propia de las primeras veces. Convertido por la apremiante necesidad en un verdadero ensalmo, el texto de la composición de 1644 era pregonado con la solemnidad carac- 
terística de las grandes ocasiones. Por supuesto, esas gastadas palabras eran incapaces de resolver nada, pero provocaban cierta sensación de alivio. Lo maravilloso es que algunas veces, tal vez no pocas, parecían atraer a la lluvia, lo que constituía la verdadera solución. Sin hacer distinción entre los chilares de Triana, los pequeños huertos de los indios de San Marcos, las parcelas de los arrendatarios del convento de La Merced y los trigales de los ricos, las lluvias de junio caían como una bendición sobre los campos resecos y lograban lo que las autoridades eran incapaces de hacer con su vetusto arsenal de composiciones, autos y pregones. Pero claro, la solución proveída por el cielo tenía un carácter provisional y uno o dos años después la crisis, indefectiblemente, se presentaba de nuevo, con fuerza redoblada.

\section{UN POTENTADO QUE NO DEJÓ DE SERLO}

En 1830, la situación era básicamente la misma que había a mediados del siglo Xvı o principios del XVIII, aunque más complicada en la medida que había crecido la población de la villa (850 habitantes en $1650,5,000$ a fines del siglo XVII, poco menos de 10,000 a fines del XVIII y unos 15,000 cuando se consumó la Independencia), lo que suponía grandes presiones sobre un recurso no elástico, por lo menos en cuanto al carácter de la tecnología empleada para aprovecharlo.

Lo que sí había cambiado, aunque nadie lo advirtió hasta que se presentaron de nuevo los problemas, era la relación entre el cabildo y los particulares. Durante toda la época colonial aquel había figurado como dotado de una autoridad de última instancia, era la representación del rey y el depositario de sus derechos, el titular indiscutible de los derechos sobre el agua y otros recursos esenciales. Todo el derecho indiano consolidaba dos "principios rectores": que el territorio pertenecía originalmente a la Corona y que los pastos y las aguas debían gozarse en común, salvo casos especiales en los que la propia Corona disponía otra cosa (Margadant 1989, 114). En el caso de los manantiales del Ojocaliente, la composición ajustada por el visitador Torres con el cabildo en 1644 establecía que, aunque estaban en terrenos de una hacienda, pertenecían "al común” y que 
era el cabildo la autoridad que podía regular su administración y arbitrar las disputas.

Al destruirse el viejo orden, las prerrogativas del cabildo empezaron a tambalearse. El antiguo marco jurídico no desapareció de la noche a la mañana ni caducó en forma automática, aunque era evidentemente el andamiaje legal de un régimen extinto. Por fuerza coexistió con la nueva Constitución federal, la del estado de Zacatecas (al que pertenecía Aguascalientes) y todas las leyes secundarias que fueron promulgándose. En el caso de los manantiales del Ojocaliente, el cabildo suponía que conservaba sus antiguos derechos, pero apareció un particular que invocando el nuevo orden legal los puso en entredicho. El derecho de propiedad ya no admitía las restricciones que eran propias del antiguo orden y el dueño de la hacienda del Ojocaliente pretendía serlo a plenitud, lo que implicaba la posesión y disfrute de los manantiales que estaban dentro de su propiedad. En realidad, como ha observado Margadant (1992, 240-241), durante las primeras décadas de vida independiente no se legisló sobre las aguas del subsuelo, lo que remitía la cuestión al derecho novohispano, el cual, a pesar de que México era ya un país independiente, seguía siendo la arena en la que se disputaba el control de ese recurso.

En este mismo marco de reacomodos que se dieron a partir de la consumación de la Independencia debe considerarse la desaparición de la Corona (titular originaria de muchos derechos), la redefinición de las relaciones entre el centro y la periferia, la creciente debilidad del poder central, la vigorización de los regionalismos y el redimensionamiento del poder de las oligarquías locales (los "potentados", como se les llama en los documentos). Como dice Aboites $(1998,34)$ :

Obviamente los ayuntamientos vendían, arrendaban y vigilaban los aprovechamientos que tenían como base sus derechos sobre determinadas corrientes. No era un dominio eminente o una propiedad originaria sobre las aguas lo que facultaba a esos cuerpos gubernamentales a intervenir; era una concesión o merced como la de cualquier particular. La autoridad que habría podido esgrimir ese dominio eminente, la Corona española, ya no 
existía; y el nuevo gobierno nacional no había reivindicado para sí ningún derecho equivalente.

Tradicionalmente, los dueños de la hacienda de Ojocaliente habían admitido que los manantiales eran "del común" y que su gestión era competencia del cabildo. Lo mismo que tantas otras, la finca salió muy mal parada de la guerra de Independencia, pues los réditos generados por las fundaciones piadosas dejaron de pagarse durante muchos años y los adeudos se volvieron inmanejables. En marzo de 1829, la hacienda le fue rematada a Tadeo Gutiérrez Solana, quien se la traspasó casi enseguida al coronel José María Rincón Gallardo, ${ }^{21}$ dueño de las haciendas pertenecientes al latifundio de Ciénega de Mata, el más extenso y rico que había en esa región del país. Al adquirir la hacienda del Ojocaliente, que limitaba por el oriente con la del Soyatal, también de su propiedad, logró comunicar la ciudad de Aguascalientes con las haciendas de su mayorazgo y poner a su disposición, por así decirlo, un "corredor privado" que le permitía ir desde Aguascalientes hasta Ojuelos, e incluso un poco más allá, hasta las goteras de la villa de San Felipe, sin salir de sus dominios. No se trataba, pues, de un ciudadano común y corriente. Una expresión muy particular de su poder y de la forma en que ciertos personajes podían diferir indefinidamente el acatamiento de las nuevas leyes lo encontramos en el hecho de que a pesar de que la propiedad vinculada ya no existía, lo que afectaba directamente su mayorazgo, él se las ingenió para conservar indivisas las haciendas que la formaban ¡hasta 1861! E incluso entonces, en medio de la guerra civil, encontró la forma de practicar una división completamente ajustada a sus necesidades y conveniencia de patriarca, pues las repartió entre sus hijos vivos, vendiendo al mismo tiempo cierto número de ranchos a sus antiguos arrendatarios y medieros (Gómez 1998, 177 y ss).

José María Rincón Gallardo nació en 1793 y fue educado en los mejores colegios de la ciudad de México. En octubre de 1810, in-

${ }^{21}$ AHEA, Fondo de Protocolos Notariales, caja 44, expediente 2, José María Calvillo, escrituras sin número contenidas en el protocolo del año 1829 , contenidas entre las fojas $148-157,170-179,186-195,195-203$ y $242-244$. 
gresó como subteniente en el segundo batallón del Cuerpo Urbano de Patriotas de Fernando VII. Ascendió rápidamente en el escalafón y en marzo de 1813 el virrey Calleja lo nombró su ayudante. En noviembre de 1815 obtuvo el grado de capitán y en septiembre de 1816 , al tiempo que moría su padre, fue nombrado teniente coronel y tomó el mando de los Urbanos de Ciénega de Mata, lo que le permitió radicarse en sus haciendas y encabezar desde ahí los esfuerzos tendientes a asfixiar los movimientos de los insurgentes (Zayas Jarero s.f., 129-131). Convertida en fortaleza, la hacienda de Ciénega de Mata resistió todos los embates de la guerrilla (Hamnett 1990, 222-224) y ganó fama de "inexpugnable" (Beltrami 1982, I, 259). En mayo de 1819, revalidó el título de marqués de Guadalupe Gallardo, que había adquirido su padre en octubre de 1802 (Zayas Jarero s.f., 81). En diciembre de 1821 Iturbide le dio el grado de coronel del ejército y poco después lo incorporó como caballero de número a la Orden de Guadalupe y lo hizo Gentil Hombre de Cámara (Ladd 1984, 200). A la caída del Imperio se radicó a sus haciendas y en 1826 solicitó su retiro del ejército, aunque gracias a una disposición del presidente Guadalupe Victoria conservó el fuero militar y el derecho al uso del uniforme. Justamente a fines de ese año fue anfitrión del ministro inglés Henry George Ward, a quien cautivó por la inteligencia y el celo puestos en el manejo de sus negocios. Según los cálculos del viajero, el latifundio de Ciénega de Mata le dejaba a su propietario una renta anual de 75,000 dólares (Ward 1981, 674). Es un hecho que, en medio de las incertidumbres que sacudieron la vida del país durante la primera mitad del siglo XIX, se convirtió en el dueño de un negocio próspero y bien administrado, un personaje que estaba en las antípodas del latifundista tradicional (Zayas Jarero s.f., 135-136). ${ }^{22}$ Un viajero francés lo definió como "uno de los mejores criollos, librepensadores y lleno de sentimientos generosos" (Beltrami 1982, I, 260). Sus méritos se acrecientan si recordamos que muchas de las fortunas acumuladas al amparo de la bonanza minera de fines del siglo XvIII en el Bajío se disolvieron con

${ }^{22}$ Confróntese la descripción que hace González Navarro (1983, 141-142) de Manuel Gándara, uno de los más ricos terratenientes sonorenses. 
una facilidad "impresionante" durante las décadas que siguieron a la guerra de independencia (Brading 1988, 242). En suma, era un producto típico del antiguo régimen que se las arregló para conservar intactos sus privilegios y acrecentar su poder económico bajo el nuevo orden republicano. Su caso nos recuerda que por sí mismos los grandes cambios institucionales no resuelven los problemas sociales; el nuevo país, soberano, independiente y con conocidos sueños de grandeza, cargaba sobre sus espaldas el peso muerto de los problemas heredados de su carácter de antigua posesión española.

Rincón Gallardo era amigo del general Santa Anna, con quien sostenía correspondencia personal y de negocios, y llegaría a ser consuegro de uno de sus más cercanos colaboradores, el general José María Tornel, ${ }^{23}$ pero en la época que nos interesa estaba más bien alejado de la política, concentrado en mejorar sus haciendas. En ese contexto debe entenderse su interés por la hacienda de Ojocaliente, que compró en 1829. Desde el siglo XVII su familia era dueńa en la plaza principal de la villa de Aguascalientes de la llamada "casa del vínculo", un palacete contiguo a la recién construida "casa municipal”. Ahí hospedó, en la Navidad de 1826, a Henry George Ward, quien calificó de "elegante" la finca. Rincón Gallardo era popularmente conocido en Aguascalientes como "el marqués", pero él prefería usar el más republicano título de "coronel”. No se interesaba en las disputas del cabildo, ni encabezaba un partido o facción. Era un gran hombre de negocios, el hacendado más importante de una vasta región que incluía Aguascalientes como uno de sus eslabones.

\section{La hacienda del Ojocaliente}

No está claro por qué compró la hacienda de Ojocaliente. ¿Simple apetito de dominio, un señor feudal que quería darse el gusto de viajar desde Aguascalientes hasta San Felipe sin salir de sus dominios? No nos parece que esa sea la razón, pues él siempre se condujo

${ }^{23}$ Ladd $(1984,20)$ dice que el general Tornel y Mendívil "se casó con la hija del último marqués de Guadalupe”. En realidad fue el hijo del general, del mismo nombre, quien se casó con Guadalupe Rincón Gallardo y Villamil, la hija mayor de José María Rincón. 
según hábitos de racionalidad económica moderna y no de simple señorío. La finca era una propiedad media, que medía dos sitios de ganado mayor y uno de menor, poco más de 4,000 hectáreas en total. Tierras de regular calidad, unas pocas caballerías de "pan llevar" y en su mayoría agostaderos. Tenía la ventaja de su contigüidad con la ciudad de Aguascalientes, ${ }^{24}$ pero su aprovechamiento estaba limitado por un hecho fundamental: las aguas del manantial pertenecían a la villa, no al propietario de la hacienda, lo que impedía aprovecharlas en el riego de terrenos.

Además, la guerra de Independencia había agravado los problemas financieros que secularmente agobiaban a las haciendas. El problema consistía en que sobre la finca se había acumulado gran cantidad de obligaciones (sobre todo censos, capellanías y fundaciones pías) que convertían al dueño de la hacienda en un simple administrador de los conventos y capellanes. Con frecuencia, lo que producía no bastaba para pagar los réditos de las hipotecas. Durante la guerra, los negocios se vinieron abajo, los cultivos se abandonaron y los censos dejaron de pagarse. Cuando el conflicto terminó, los acreedores iniciaron penosos y largos procesos para tratar de recuperar lo que se les debía. Lo mismo que muchas otras, la hacienda del Ojocaliente quebró y en marzo de 1829 fue rematada a favor de Tadeo Gutiérrez Solana. Su precio se fijó en 29,225 pesos, que no hubo necesidad de desembolsar, pues la mayor parte siguió reconociéndose a favor del convento de monjas de Santa Isabel en la ciudad de México, la colecturía de diezmos de la catedral de Guadalajara, la parroquia de Aguascalientes y demás acreedores. Por ello mismo, resulta intrigante que unos pocos meses después Gutiérrez Solana le traspasara la hacienda a Rincón Gallardo.

Al parecer y en forma hasta cierto punto paradójica, la razón fue precisamente el agua de los manantiales y la construcción de unos bańos públicos, que prometían ser un buen negocio. Si esta hipótesis es válida, Rincón Gallardo habría advertido que el nuevo orden legal permitía replantear el tema del control de las aguas del manan-

${ }^{24}$ El congreso del estado de Zacatecas le había concedido ese título en 1824. AHEZFPL, serie Comisión de Puntos Constitucionales, caja 1 (1822-1824) documento sin número. Además, Amador 1982, II, 294-295. 
tial. Había un antecedente muy inmediato: en 1808, el dueño de la hacienda le pidió al virrey autorización para construir unos baños, aunque no fue sino hasta 1821 cuando el ayuntamiento impulsó su construcción, obteniendo entre algunos vecinos los fondos necesarios. ${ }^{25}$ Desde su apertura, los "Baños de Abajo" o de "Los Arquitos" se convirtieron en un importante arbitrio municipal. Estaban construidos en tierras de la hacienda, pero el único beneficio que le reportaban a su dueño era el pago de un canon. En términos de nuestra hipótesis, al comprar la hacienda Rincón Gallardo no quería "ensanchar sus dominios", sino hacer un negocio, concretamente construir unos baños públicos que rivalizaran con los de Los Arquitos. Pero eso suponía la propiedad del agua, no sólo de la tierra. Aparentemente, Rincón Gallardo pensó que el nuevo orden republicano, liberal y protector de los derechos de los particulares, le garantizaba el disfrute irrestricto de su hacienda, lo que evidentemente incluía el manantial.

\section{LA CONSTRUCCIÓN DE LOS BAÑOS}

A principios de 1831, apenas un año después de haber adquirido la hacienda, Rincón Gallardo se puso a construir unos "cuartos para baño", que obviamente iban a utilizar agua del manantial. Es importante hacer notar que no consideró necesario avisar o pedir permiso al cabildo, pues partía del supuesto de que la hacienda y todos sus "llenos" le pertenecían de manera plena, pudiendo él hacer lo que mejor le pareciera. El ayuntamiento, heredero de una tradición secular que en la localidad le daba un poder incontrastable y alarmado ante la posibilidad de que disminuyera el caudal de agua que bajaba a la ciudad, ordenó a mediados de abril la suspensión de las obras. Rincón Gallardo se hizo el sordo y continuó los trabajos, lo que enojó al cuerpo municipal, que instruyó a uno de sus alcaldes para que personalmente supervisara la demolición de los cuartos de baños construidos. Alarmado, el apoderado de Rincón Gallardo le dijo al comandante Ángel Guzmán que sabía "por conductos segu-

${ }^{25}$ AGMA-FH, caja 477, exp. 24. El asunto es mencionado por Topete $(1973,68)$. 
ros" que se había pedido auxilio de la "tropa" (seguramente milicia cívica) "para con ella pasar a la hacienda de Ojo Caliente y destruir los baños y por este medio insolentar al pueblo y enconarlo en contra del ciudadano coronel Gallardo, dueño de aquella finca”. Dadas las circunstancias, lo único que podía hacerse para evitar una de esas "asonadas escandalosas que son tan trascendentales a la quietud pública y no tienen más origen que satisfacer pasiones innobles y nada de justicia", era "sostener el fuero del citado coronel, que ni quiere ni puede renunciar”. Guzmán, que estaba muy al tanto del peso político y la riqueza del "ciudadano Gallardo", hizo lo que se le pedía y además le envió al alcalde Antonio Rodríguez Leal una misiva pidiéndole que suspendiera cualquier diligencia en tanto se determinaba a qué autoridad interesaba el asunto, si a la civil (local), por ser un asunto de aguas, o a la militar (federal), por tratarse del fuero de un miembro del ejército. ${ }^{26}$

Es importante hacer notar que Rincón Gallardo usó su fuero como parapeto y que trató de fijar la discusión en términos que le eran favorables, pues en cierta forma el tema ya no eran los derechos sobre el agua, sino las "asonadas", "la quietud pública”, las "pasiones innobles", lo que le permitía presentarse como defensor del orden y no como mezquino promotor de sus intereses personales. Otra vertiente del problema tiene que ver con las diferencias crecientes entre el ejército federal (al que pertenecía Rincón Gallardo), cuyos miembros tenían fuero, y las milicias cívicas de los estados, que no disfrutaban ese privilegio. Las diferencias y los celos entre ambos no hicieron más que crecer, hasta que estallaron en 1835, cuando se ordenó la disolución de las milicias cívicas, "defensoras últimas de la soberanía de los estados”, según el doctor Mora y otros de sus panegiristas, precipitándose la caída de la primera república federal y de pasada la creación del departamento de Aguascalientes (Gómez 1994, 111-114).

En un escrito fechado el 11 de mayo de 1831, Rincón Gallardo lamentó ante el juez de lo civil los abusos de los que era víctima y argumentaba que como dueño de la hacienda del Ojocaliente podía "hacer de lo suyo lo que mejor le agrade, según el art. $7^{\circ}$, dro. $3^{\circ} \mathrm{de}$

${ }^{26}$ AJMRG, 2, 17, 1. 
nuestra constitución, sin que autoridad alguna pueda embarazárselo”. En el mismo escrito, un párrafo adelante, insistía en su derecho de "continuar sin estorbo alguno la fábrica de sus baños, y que ninguna autoridad pueda volverle a estorbar, que haga de su hacienda y en su hacienda lo que mejor le agradase", pero esta vez invocaba "la ley 1 ra., 2 da. y $7 \mathrm{ma}$, título 13 , libro $4^{\circ}$ de la Nueva recopilación" ${ }^{27}$ Es interesante advertir que la argumentación remite tanto al viejo orden jurídico como al nuevo, que según la sesgada interpretación de Rincón Gallardo coincidían en su defensa del derecho que asistía a los particulares de hacer con sus bienes lo que quisieran.

El juez falló a favor de Rincón Gallardo, lo que irritó a algunos munícipes, alguno de los cuales propuso que se adoptaran medidas de fuerza. Por lo pronto, sin embargo, la cordura o el temor se impusieron y se encargó a una comisión especial el estudio del asunto, lo que permitió la integración de un grueso expediente con todos los antecedentes del problema, incluida la famosa composición de 1644, que funcionaba como verdadera piedra angular de los derechos del cabildo sobre el agua. ${ }^{28}$

Curiosa y sugestivamente, en el alegato que presentó el cabildo no se cita esa composición ni se invocan los derechos y privilegios que en el marco del antiguo régimen tenía la corporación municipal, que da la impresión de encontrarse desconcertada, en una especie de vacío o desamparo jurídicos, a merced del poder y el dinero de un particular. Ello remite a la "debilidad" de los ayuntamientos y del poder público en general "frente a los grandes oligarcas", algo que se experimentó en Querétaro, con Cayetano Rubio, o en Toluca, con los empresarios cerveceros (Aboites 1998, 49). De hecho, el cabildo tardó más de un año en estudiar el asunto y preparar un dictamen, el cual fue firmado por la comisión que especialmente se formó el 31 de agosto de 1832. En éste se proponía que se permitie-

${ }^{27}$ AJMrg 2, 17, 1, fojas 1-3. Rincón Gallardo no invoca la Recopilación general de leyes de las Indias de Aguiar y Acuña, ni tampoco la Recopilación de las Indias de León Pinelo, sino la Nueva recopilación, el corpus legal formado a instancias de Felipe II, publicado en 1567 y cuya vigencia alcanzaba todos los territorios de la Corona de Castilla, no sólo las Indias. El énfasis es nuestro.

${ }^{28}$ Se trata precisamente del que llamamos Documento Paullada, referido en la nota 1 de este artículo. 
ra a Rincón la construcción de dos baños, a cambio de lo cual éste entregaría al ayuntamiento quinientos pesos y cedería, en calidad de censo enfitéutico, ${ }^{29}$ el terreno en el cual brotaban las aguas, a razón de veinte reales al año por cada solar, "sin que se entienda en esta tierra aquella que sirve actualmente al tránsito de las aguas, como servidumbre antigua y pacífica, para que la ciudad disfrute estos terrenos con el seńorío que corresponde a esta clase de arrendamientos". Además, el dictamen reconocía los derechos que asistían a Rincón en calidad de dueño de la hacienda, pero también señalaba que el ayuntamiento usaba las aguas del manantial como propias desde hacía más de doscientos años y que en consecuencia era necesario que el coronel y el cuerpo municipal "se protestasen mutualmente el mejor respeto y armonía sobre los goces que ambos a la fecha disfrutan legalmente". Por último, en un tono conciliador, se recordaba que Rincón "tiene hecha una oferta apreciable sobre la grandiosa obra de la introducción de el agua del río" y que era de esperarse, habida cuenta de las "notorias facultades" del oferente y de su calidad de buen hijo de Aguascalientes, que el proyecto se materializara. ${ }^{30}$

Es revelador que un ayuntamiento constitucional acuda en su defensa al arsenal jurídico del antiguo orden: enfiteusis, señorío, servidumbre..., pero la verdad es que no había otro porque el régimen republicano en ascenso tardaría no años, sino décadas en perfeccionarse y contar con una normatividad ad hoc. Refiriéndose a "las leyes citadas en aquel escrito" (la Nueva recopilación), el presidente del cabildo dijo que en su opinión "algunas" de ellas "estaban derogadas por pugnar con el sistema que nos rige" y que su lenguaje "le parecía en un todo extraño" (databan del siglo XvI); en cualquier

${ }^{29}$ La enfiteusis supone la cesión del dominio útil de un inmueble a cambio del pago anual de un canon e implica la disociación entre la propiedad legal de un bien y su aprovechamiento (Tomás y Valiente 1997; Clavero 1986).

${ }^{30}$ AJMRG, 2, 17, 3. Se conocen bien las "notorias facultades" de Rincón Gallardo, pero no se sabe nada de su oferta sobre "la grandiosa obra de la introducción de el agua del río". En enero de 1827, el gobierno del estado de Zacatecas le había prestado al cabildo de Aguascalientes cuatro mil pesos "para concluir la obra de una saca de agua dulce que tiene emprendida", obra a la que probablemente aluda el supuesto ofrecimiento de Rincón Gallardo, del que no tenemos ninguna evidencia (AHEA, FPN, José María Calvillo, 1827, escritura sin número, fojas 24-26). 
caso sólo se mantenían vigentes "las que no pugnen con nuestro sistema”. Además, le parecía incuestionable el derecho de un "hombre rico y poderoso" a adquirir "las propiedades de algún pueblo por contrato". En estas opiniones está expresado con gran claridad el conflicto entre la vieja normatividad y la nueva, entre el antiguo régimen y la república. La indefensión del cabildo, o el hecho de que en cierta forma era consciente de estar usando armas jurídicas caducas o inapropiadas, se revela en el tono defensivo, conciliador y contemporizador de sus escritos. Es como si hubiera renunciado al sentimiento de superioridad, esa cierta arrogancia que siempre lo había caracterizado en sus enfrentamientos con los particulares. Recordemos que la sociedad colonial tenía un carácter esencialmente corporativo y que las personas en tanto que individuos no significaban nada ni tenían derechos (Ávila 1999, 23). En otros tiempos, como vimos, se había ordenado la destrucción de plantíos propiedad de particulares, aunque fueran éstos miembros de la propia corporación municipal o incluso alcaldes mayores. Ahora se llamaba a la conciliación, al respeto mutuo, a la armonía; se reconocía el derecho de un rico para contratar la adquisición de los bienes del común, antiguamente inalienables. ¡Qué cambio tan inmenso!

\section{El CANTo Del Cisne}

El 7 de septiembre de 1832, muy avanzada ya la construcción de los baños y posiblemente firmados los acuerdos entre el coronel Rincón Gallardo y el cabildo, en cualquier caso hechas las paces entre las partes, el síndico procurador Manuel Peña, "obligado por el solemne juramento que presté de defender [los] intereses y derechos [públicos]", presentó una fogosa representación que bien puede leerse como una apoteosis, la culminación de la tradición jurídica antigua, pero al mismo tiempo la expresión de su invalidez o su falta de adecuación a los nuevos tiempos. En este sentido, "el canto del cisne" de las prerrogativas y derechos que habían tenido siempre los cabildos:

Una larga y dolorosa experiencia nos tiene acreditados en nuestras propias cabezas que los potentados han sido en todo tiempo las terribles polillas de 
los pueblos; sólo ellos pudieron concebir el bárbaro designio de reducirlos a la clase miserable de esclavos, de hacerlos sus tributarios y que los adoren como dioses; por algo fueron distinguidos con títulos, cruces y galones en el antiguo execrable y despótico sistema, y por algo los ciudadanos los señalan con el dedo cuando respiran bajo nuestras instituciones liberales. ${ }^{31}$

Rincón Gallardo era uno de esos "potentados”, indiferente ante los derechos de los pueblos y sordo ante los reclamos de las autoridades civiles; un hombre al que "se ha visto desobedecer con descaro y orgullo las providencias que ha dictado el ayuntamiento prohibiendo la continuación de una obra que hacía en perjuicio de la fuente pública"; un avaro "sin patria, sin religión y sin fama”, incapaz "de una sola acción buena” e ignorante de la idea de justicia cuya verdadera pretensión, protestas de buena fe aparte, consistía en apoderarse de toda el agua del Ojocaliente, imponiendo a la ciudad un vergonzoso pupilaje. La construcción de los nuevos bańos tendría como consecuencia la disminución del volumen de agua administrado por el ayuntamiento. La razón, el bien público y la ley clamaban que el problema sólo podía ser resuelto mediante la destrucción de los baños y el rechazo de las "zalameras" propuestas de Rincón, "ese hombre atrevido que quiere complacerse en las lágrimas de los infelices hortelanos de este suelo". En cuanto a los antiguos baños de Los Arquitos, cuyo aprovechamiento tenía concesionado Rincón, el procurador Peña señalaba que el servicio iba de mal en peor: "antes valía un real el baño y lo permitían por dos y hasta por tres horas, y hoy cuesta doble y en algunos casos cuádruplo, sin que pase de media hora porque quiebran la cabeza a golpes en la puerta y paredes". ${ }^{32}$ Peña proponía que en el aprovechamiento de los antiguos baños Rincón y el ayuntamiento fueran a medias con los beneficios, "por ser el pueblo dueño del agua" y porque la "justicia conmutativa” indicaba

${ }^{31}$ Una copia incompleta de la representación del procurador Peña en AJMRG, 18, 292, 3, fojas 40-48 (las cursivas son mías). El original no se conserva, pues el archivo colonial y de la primera mitad del siglo xix del cabildo de Aguascalientes fue pasto de las llamas con ocasión de una incursión en la ciudad del bandido Juan Chávez, el 12 de abril de 1863 (La Revista, 16 de abril de 1863).

${ }^{32}$ Nótese, de pasada, que esta queja remite a las nuevas ideas acerca de la higiene personal y el baño que había traído consigo la Ilustración. 
que "cuando dos son dueños de una cosa hagan iguales partes de sus rendimientos". Que la corporación municipal hiciera "brillar la justicia que le asiste" y que descargara sobre Rincón "el golpe que debe poner fin a su prurito de ofender al público", era la postrer demanda del exaltado procurador. De todas formas, en caso de que sus consejos fueran ignorados, Peña conservaría "el placer de haber hecho lo posible" en defensa de los intereses públicos, "cumpliendo con los deberes de ciudadano y con los muy estrechos de síndico procurador".

El procurador, convencido de que tenía el deber "de reclamar los derechos del público, que en vano quieren atropellarse, despreciando las leyes que los guardan", convocaba en su auxilio diversas disposiciones "que he podido encontrar en la Novisima recopilación", que como se sabe fue publicada en 1805 a instancias de Carlos IV; en todo caso, era el corpus normativo de lo que él mismo llamaba "antiguo, execrable y despótico sistema”, aunque no advertía ninguna contradicción en ello. Concretamente, citaba la prohibición que tenían los concejos de enajenar sus ejidos y montes, "mas que sean para el pro comunal de dichas ciudades y villas" (ley segunda, título veintiuno, libro séptimo), y aunque reconocía que "esta disposición no habla precisamente de aguas, las comprende tácitamente”. Recordaba también la obligación que tenían los cabildos de recurrir a una subasta pública cuando sus "bienes propios y rentas [...] se hubieren de arrendar" (ley cuarta, titulo dieciséis, libro séptimo), lo que implicaba que, si se rentaba el agua del Ojocaliente, debía hacerse mediante remate público, en el cual no podía participar el general Rincón Gallardo, pues tratándose de los propios de la villas y ciudades no debía consentirse "que los arrienden personas poderosas [...], por sí ni por interpósitas personas" (ley séptima, título dieciséis, libro séptimo). Y para rematar la faena, Peña enviaba un venenoso mensaje a los regidores que apoyaban a Rincón y a la postre evitarían con su voto la destrucción de los baños; había una ley, recordaba, que decía que "algunos caballeros y personas poderosas toman las rentas y términos y jurisdicciones de las ciudades y villas, y hacen otros agravios en daño de la cosa pública”, lo que sólo podían hacer validos del "favor" de "los regidores y algunos letrados naturales de ellas", quienes estorbaban "que no se siga la justicia del tal pueblo contra los tales"; por ello se prescribía que esos personajes 
no den favor a tales caballeros o personas poderosas [...] en público ni secreto, en los tales pleitos que contra ellos tuvieren [...] y que todos sean en una voluntad en guardar y defender y proseguir la justicia de los propios y rentas, y términos y jurisdicciones, y privilegios que sobre ello los tales pueblos tienen, so pena que por el mismo hecho pierdan los oficios y no sean recibidos en los ayuntamientos (Ley tercera, título veintiuno, libro séptimo). ${ }^{33}$

Esta representación se inscribe con claridad en esa larga tradición novohispana que atribuía a los ayuntamientos el deber de cuidar los derechos de los pueblos, pero navega con dificultades entre dos órdenes jurídicos, el del antiguo virreinato espańol y el del nuevo país independiente. En una primera lectura, parece un furioso ataque contra el antiguo régimen: "ciudadanos" contra "potentados"; instituciones liberales contra "títulos, cruces y galones". No hacía mucho (1826) que había circulado en la ciudad un impreso firmado por "un patriota" que retóricamente preguntaba:

¿por qué la casa conocida por El Vínculo [iprecisamente la residencia urbana del coronel Rincón Gallardo!] tiene aún sobre cada una de sus ventanas un gran escudo de armas, es decir, uno de aquellos monumentos con que los seńores reyes de Espańa premiaban a nuestros antiguos nobles su avezamiento $[s i c]$ a la esclavitud, sus servicios feudales y el dinero que les chupaban, todo en perjuicio de nuestra malhadada Patria. ${ }^{34}$

Sin embargo, es por lo menos curioso advertir que para sustentar sus acusaciones el regidor Peńa recurre precisamente a la Novisima recopilación, un compendio formado en las postrimerías del "antiguo y despótico sistema", y no a las leyes de "nuestro feliz sistema republicano federal".

${ }^{33}$ Todas estas referencias entre las fojas 46 y 48 de la representación citada en la nota 31. Las leyes mencionadas se encuentran entre las pp. 382-384 y 477-478 del tomo tercero de la Novisima recopilación de 1805, cuyo texto he cotejado.

${ }^{34}$ AHEz, Fondo Ayuntamiento, serie Correo Político, caja 1, expediente COI E14 (1826). Además, Rojas 1999, 187-188. 
Sorprende, y mucho, el valor personal del procurador Peńa, pues estaba desafiando a un personaje rico y poderoso, uno de los más grandes latifundistas del país, un oficial del ejército que explícitamente había invocado su fuero. De hecho, el único que lo secundó fue el síndico Ignacio Marín, quien dijo que Rincón Gallardo "escandalosamente se ha burlado tres veces del I. Ayuntamiento", aludiendo a la reiterada pero nunca acatada orden de abatir los nuevos cuartos de baño. El presidente del cabildo y otros regidores le sugirieron que mejor retirara su representación, pues Rincón Gallardo lo podía demandar por injurias.

\section{Desenlace}

Finalmente se sometió a votación si se ordenaba o no la destrucción de los nuevos baños. Peña y Marín perdieron cinco a cuatro, lo que revela que las opiniones en el seno del cabildo estaban muy divididas y que el procurador Peńa no estaba tan solo como parecía, aunque bien había anticipado que una mayoría de regidores le darían "su favor" al "potentado Gallardo". Tampoco se sabe qué hubiera pasado en caso de que ganaran, pues en tres ocasiones anteriores la orden de destruir los baños había sido ignorada. Poco después, tal vez cuando Peña había dejado su cargo de procurador se autorizó el funcionamiento de todos los cuartos de baño existentes y de los que en lo sucesivo se edificaran, con el argumento de las ganancias obtenidas por la higiene pública y las finanzas municipales.

En julio de 1836, Rincón Gallardo le vendió la hacienda del Ojocaliente a Josefa Rincón Gallardo, su parienta, por cierto, esposa de otro "potentado", el coronel Francisco Flores Alatorre, que por más señas era en esos momentos gobernador del recién creado departamento de Aguascalientes (Gómez 1994, 147). Para entonces la hacienda contaba con catorce cuartos de baño, "en nada obligados a esa ciudad", según se tuvo el cuidado de asentar en la escritura de compraventa. ${ }^{35}$

${ }^{35}$ AHEA, Fondo de Protocolos Notariales, José María Calvillo, 1836, s. n., 205-206 y 1836, s. n., 236-237(caja 51, expediente 2). 
Durante muchos años no se volvieron a poner en duda los derechos de los dueños de la hacienda a usar las aguas del manantial en los baños, tanto los "de arriba” o nuevos, construidos por Rincón Gallardo, como en los "de abajo", antiguos o de Los Arquitos, que pertenecían al cabildo. En marzo de 1843, cuando Josefa Rincón Gallardo le vendió la hacienda a Concepción Gámez de Serrano se asentó: "Le corresponde a Ojocaliente el uso del agua que mana del ojo de agua caliente en los dieciséis baños que hay fabricados, saliendo de allí para los regadíos de esta ciudad, y dominio directo del terreno en que están sentados los baños de abajo, que administra el Ilustre Ayuntamiento, por los que se le paga a la hacienda el censo anual respectivo". Y se añadía:

Tiene además la finca el derecho de servirse de el agua, fabricándose un molino en el punto que no perjudique dichos regadíos, por habérsele así concedido en despacho que expidió el juez de composiciones don Tomás Terán de los Ríos en la ciudad de Guadalajara el 13 de julio de 1724 [...] y no puede disponer para otro objeto que el de los baños del agua que sale del Ojocaliente, ni perjudicarle en manera alguna, por ser del común de esta capital, a quien pertenece también la acequia por donde se conduce, teniendo la hacienda la servidumbre onerosa de ella sobre las tierras por donde pasa. ${ }^{36}$

Al final de cuentas, ¿quién ganó, qué criterios se impusieron? Los dueños de la hacienda aceptaron que el agua de los manantiales le pertenecía "al común", representado por la corporación municipal, pero al mismo tiempo se reconoció su derecho a tomar toda el agua que necesitaban para sus baños. Pareciera una simple componenda, una de esas soluciones que tratan de dejar conformes a las dos partes sin darle la razón a ninguna; un acuerdo inspirado por mitades por el sistema jurídico colonial, que primaba los derechos de la corporación municipal, y por el emergente sistema republicano, que le concedía al ciudadano ciertos derechos inalienables, como el de propiedad. Así seguirían las cosas hasta 1856, cuando la ley de des-

${ }^{36}$ Escritura otorgada ante el escribano José María Calvillo el 24 de marzo de 1843, transcrita en el expediente que se conserva en AHEA, Fondo del Poder Judicial, Ramo Civil, 1883, 188. Las cursivas son mías. 
amortización de bienes de las corporaciones supondría para todos los cabildos un golpe definitivo y mortal.

Por otra parte, este caso nos recuerda que en las primeras décadas de la vida independiente las disputas seguían arbitrándose "con base en procedimientos legales y costumbres de origen colonial”. La estructura política novohispana había sido destruida, pero no su andamiaje legal. Como afirma Aboites $(1998,51)$, "la fragmentación política que trajo el surgimiento del nuevo país contribuyó a hacer más notable ese manejo local del agua”. El fortalecimiento de las oligarquías locales y la influencia que ejercían sobre los cabildos, tribunales, legislaturas y sobre los mismos gobernadores de los estados alentaron la "expansión de los intereses privados sobre pueblos y comunidades, en un periodo en el que el Estado no veía con malos ojos el avance de la privatización y de la mercantilización de la economía”.

\section{ArCHIVOS}

AgMA, Archivo General Municipal de Aguascalientes AJMrg, Archivo del general José María Rincón Gallardo AHEA, Archivo Histórico del Estado de Aguascalientes AHEZ, Archivo Histórico del Estado de Zacatecas

\section{BibliografíA CITADA}

Aвoites Aguilar, Luis, El agua de la nación. Una historia politica de México (1888-1946), México, Ciesas, 1998.

Aguiar y Acuña, Rodrigo de y Juan Francisco Montemayor y Córdoba de Cuenca, Sumarios de la Recopilación general de leyes de las Indias Occidentales, México, unAM, FCE, 1994. Presentación de José Luis Soberanes Fernández, Prólogo de Guillermo F. Margadant y Estudio introductorio de Ismael Sánchez Bella [Edición original: Madrid, 1681.]

Amador, Elías, Bosquejo histórico de Zacatecas, 2 tomos, Zacatecas, 1982.

Ávila, Alfredo, En nombre de la nación. La formación del gobierno representativo en México (1808-1824), México, Taurus, CIDE, 1999. 
Beltrami, J. C., “Le Mexique”, en Margo Glantz, Viajes en México. Crónicas extranjeras, Colección SepOchentas, núm. 34, México, SEP, FCE, 1982.

Brading, David A., Haciendas y ranchos del Bajio. León, 17001860, México, Editorial Grijalbo, 1988.

Calvo, Thomas, Poder, religión y sociedad en la Guadalajara del siglo XVII, México, CEMCA, Ayuntamiento de Guadalajara, 1991.

Clavero, Bartolomé, "Enfiteusis, ¿qué hay en un nombre?”, Anuario de historia del derecho español, núm. 56, 1986, 467-520.

Chevalier, Francois, La formación de los latifundios en México. Tierra y sociedad en los siglos XVI y XVII, México, Fondo de Cultura Económica, 1976.

Gómez Serrano, Jesús, La creación del estado de Aguascalientes (1786-1857), México, Conaculta, Colección Regiones, 1994. , Ciénega de Mata. Desarrollo y ocaso de la propiedad vinculada en México, Aguascalientes, UAA, El Colegio de Jalisco, 1998. , La guerra chichimeca, la fundación de Aguascalientes y el exterminio de la población aborigen (1548-1620). Un ensayo de reinterpretación, Zapopan, El Colegio de Jalisco, Ayuntamiento de Aguascalientes, 2001.

, "La lucha por el control del agua en la villa de Aguascalientes durante los siglos XVII y XVIII", en Manuel Miño Grijalva y Édgar Hurtado Hernández, coords., Los usos del agua en el centro y norte de México. Historiografía, tecnología, conflictos, Zacatecas, UAZ, 2005, 36-81.

González Alonso, Benjamín, "La fórmula 'Obedézcase pero no se cumpla' en el derecho castellano de la Baja Edad Media”, Anuario de historia del derecho español, núm. 50, 1980, 469-488.

González Navarro, Moisés, Anatomía del poder en México, 18481853, México, El Colegio de México, 1983.

Gutiérrez, José Antonio, Historia de la Iglesia Católica en Aguascalientes, vol. I, Aguascalientes, UAA, Obispado de Aguascalientes-Universidad de Guadalajara, Parroquia de la Asunción de Aguascalientes, 1998.

Hamnett, Brian R., Raices de la insurgencia en México. Historia regional 1750-1824, México, Fondo de Cultura Económica, 1990. 
LADD, Doris M., La nobleza mexicana en la época de la independencia, México, Fondo de Cultura Económica, 1984.

León Pinelo, Antonio de, Recopilación de [las leyes de los Reinos de] las Indias, México, Miguel Ángel Porrúa, Escuela Libre de Derecho, Edición y estudio preliminar de Ismael Sánchez Bella 1992 [Edición original: Madrid, 1680].

LOCKHART, James, El mundo hispanoperuano, 1532-1560, México, Fondo de Cultura Económica, 1982.

Margadant S., Guillermo Floris, "El agua a la luz del derecho novohispano. Triunfo de realismo y flexibilidad", Anuario Mexicano de Historia del Derecho, vol. I, 1989, 113-146.

"Las aguas del subsuelo en el Derecho Indiano. Realidad histórica versus dogma abstracto en la estructura general del derecho indiano. El problema de la vigencia de normas surgidas de errores científicos", Anuario Mexicano de Historia del Derecho, vol. IV, 1992, 239-258.

,'Los pobres indios, ¡cenicientos de la justicia mexicana!' ¿Correcto o falso? Un interesante litigio sobre aguas del río Querétaro, de 1758 a 1763", Anuario Mexicano de Historia del Derecho, vol. vIII, 1996, 286-308.

Mota Padilla, Matías de la, Historia del reino de Nueva Galicia en la América septentrional, Guadalajara, Instituto Jalisciense de Antropología e Historia, 1973.

Novisima recopilación de las leyes de España. Dividida en XII libros En que se reforma la Recopilación publicada por el Señor Don Felipe II en el año de 1567, reimpresa últimamente en el de 1775: Y se incorporan las pragmáticas, cédulas, decretos, órdenes y resoluciones Reales, y otras providencias no recopiladas y expedidas hasta el de 1804. Mandada formar por Carlos IV, cinco tomos, Madrid, 1805.

Rojas, Beatriz, Las instituciones de gobierno y la élite local. Aguascalientes del siglo XVII hasta la Independencia, México, El Colegio de Michoacán, Instituto Mora, 1998.

, En los caminos de la historia, Aguascalientes en el siglo XVIII, Aguascalientes, CIEMA, 1999.

SÁnchez Rodríguez, Martín, "El mejor de los titulos". Riego, organización social y administración de recursos hidráulicos en el Bajio 
mexicano, México, El Colegio de Michoacán, Gobierno del Estado de Guanajuato, Comisión Estatal del Agua, 2005.

SuÁrez Cortez, Blanca Estela, "Poder oligárquico y usos del agua: Querétaro en el siglo XIX (1838-1880)", en Historia de los usos del agua en México. Oligarquías, empresas y ayuntamientos (18401940), México, CNA, CIESAS, IMTA, 1998, 17-103.

Tomás y Valiente, Francisco, Manual de historia del derecho español, Madrid, Tecnos, 1997.

Topete del Valle, Alejandro, Aguascalientes. Guía para visitar la ciudad y el estado, Aguascalientes, edición del autor, 1973.

, Estampas de Aguascalientes, Aguascalientes, fonapas, 1980.

Tortolero Villaseñor, Alejandro, El agua y su historia. México y sus desafíos hacia el siglo XXI, México, Siglo XXI Editores, 2000.

Ward, Henry George, México en 1827, México, Fondo de Cultura Económica, Biblioteca Americana, 1981.

Zayas Jarero Guarneros y Tolsá, Pablo, Las casas Rincón Gallardo y Romero de Terreros, México, edición del autor, s.f.

FECha de RECEPCión Del artículo: 22 de julio de 2011

FECHA DE RECEPCIÓN DE LA VERSIÓN FINAL: 28 de febrero de 2012 